\section{ODONATA IN IRRIGRATED RICE ECOSYSTEM OF MADURAI, TAMIL NADU}

\author{
M. Kandibane, N.R. Mahadevan and K. Gunathilagaraj \\ Agricultural College and Research Institute, Madurai, Tamil Nadu \\ 625104, India.
}

Order: Odonata

Suborder: Zygoptera

Family: Coenagrionidea

Subfamily: Ischnurinae

\section{Ischnura delicata Hagen}

Material examined: Five females and two males during kharif 2000; three females and two males during rabi 2000; four females and three males during kharif 2001

Distribution: Uttar Pradesh, Punjab, Himachal Pradesh and Tamil Nadu.

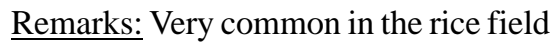

\section{Subfamily: Agriocneminae}

Odonata is a palaeopherous order of Insecta which consists of only predaceous insects. In rice ecosystem, nymphs and adults are aquatic and aerial predators, respectively of some agricultural pests. All Odonata are found close to fresh water, although adult dragonflies often venture out for some distance over land, foraging for food. Naiads of Odonata are predators of tadpoles, mosquito larvae and larvae of Ephemeroptera in irrigated rice system, while, adults are aerial predators of adult herbivores, stem borers, leaf folders and hairy caterpillars. Conserving Odonata in rice ecosystem helps in natural biological control of rice insect pests.

Prasad and Varshney (1995) gave a check list of Indian odonates lisiting three suborders, 17 families, 139 genera and 499 species and subspecies. However, Tyagi (1997) reported 500 species and subspecies after revising Fraser's works $(1933,1934,1936)$ and of Prasad and Varshney (1995). He has mentioned that following Indian independence, due to changes in the political boundaries, the number of Odonata species and subspecies occuring in India has been reduced by 75 species. Gunathilagaraj et al. (1999) reported 16 species of Odonata from rice fields of Coimbatore region. Fourteen species of Odonata from Courtallam region of Tamil Nadu were reported by Palot and Soniya (2000). Asaithambi and Manickavasagam (2002) reported 24 species of Odonata from rice fields of Annamalai University. Diversity of Odonata has not been studied earlier from Madurai, Tamil Nadu, hence an attempt was made to study the diversity of Odonata in irrigated rice ecosystems of Agricultural College and Research Institute, Madurai, Tamil Nadu.

The Agricultural College and Research Institute is located in Madurai District at an attitude of about $147 \mathrm{~m}$. The temperature varies between 24.4 and $36.5^{\circ} \mathrm{C}$. The area receives water from Vagai Dam. Annual rainfall of the study site is $893 \mathrm{~mm}$, mostly from the northeast monsoon during July to November.

\section{Agriocnemis femina femina (Brauer)}

Materials examined: 50 females and 30 males during kharif 2000; 20 females and 10 males during rabi 2000; 30 females and 10 males during kharif 2001 .

Distribution: Assam, West Bengal and South Andaman Islands.

Remarks: Common during kharif and rabi 2000 and 2001 in the paddy field.

\section{Agriocnemis pygmaea (Rambur)}

Materials examined: Two females and three males during kharif 2000; one female and one male during rabi 2000; five females and two males during kharif 2001.

Distribution: Throughout India.

Remarks: Very common in paddy fields.

\section{Suborder: Anisoptera \\ Family: Aeshnidae \\ Subfamily: Anactinae}

\section{Anux guttatus (Burmeister)}

Material examined: One female and one male.

Distribution: Throughout India.

Remarks: Collected during kharif 2000 in the paddy field. 
Family: Libellulidae

Subfamily: Sympatrinae

\section{Crocothemis servilia (Drury)}

Material examined: Eight females and five males during kharif

2000; five females and four males during kharif 2001.

Distribution: Throughout India

Remarks: Common in rice ecosystem

\section{Diplacodes trivialis (Rambur)}

Material examined: 10 females and eight males during kharif 2001; 12 females and one male during kharif 2001.

Distribution: Throughout India

Remarks: Common in paddy fields

Subfamily: Libellulinae

Orthetrum sabina (Drury)

Material examined: Four females and two males during kharif 2000; two females and one male during kharif 2001

Distribution: Throughout India

Remarks: Specimens mostly collected from paddy field

\section{Subfamily: Pantalinae}

\section{Pantala flavescens (Fabricius)}

Material examined: 30 females and 25 males during kharif 2000 ; 25 females and 20 males during kharif 2001.

\section{Distribution: Cosmopolitan.}

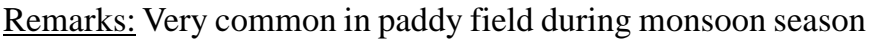

\section{Trapezostigma limbata (Desjardins)}

Material examined: One female and during kharif 2001.

Distribution: Throughout India.

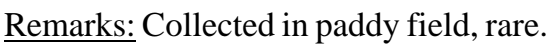

\section{Subfamily: Rhyotheminae}

\section{Rhyothemis variegata (Linnaeus) \\ Material examined: One female}

Distribution: Throughout India

Remarks: Collected during kharif 2001

A total of 12 species of Odonata under three families and 12 genera were collected and identified during the survey. Among the collected dragonflies, Pantala flavescens (Fabricius), Crocothemis servilia (Drury) and Diplacodes trivialis (Rambur) were more abundant during monsoon. The abundance of other species of dragonflies that were collected in rice ecosystem was comparatively less.

Among the three species of damselflies, Agriocnemis femina femina (Brauer) was more abundant followed by Agriocnemis pygmaea (Rambur) and Ischnura senegalensis (Rambur). Agriocnemis pygmaea and Ischnura senegalensis were collected during kharif 2001 in irrigated rice ecosystem. Abundance of Odonata in rice ecosystem mainly depends on availability of detritivores in aquatic ecosystem as they are the food source of the naiads.

\section{References}

Asaithambi, M. and S. Manickavasagam (2000). Odonata of Annamalai University, Annamalai Nagar, Tamil Nadu, India. Zoos' Print Journal 17(2): 704-706.

Fraser, F.C. (1933). Fauna of British India including Ceylon and Burma, Odonata. Vol. 1. Taylor and Francis Ltd., London.

Fraser, F.C. (1934). Fauna of British India including Ceylon and Burma, Odonata. Vol. 2. Taylor and Francis Ltd., London.

Fraser, F.C. (1936). Fauna of British India including Ceylon and Burma, Odonata. Vol. 3. Taylor and Francis Ltd., London.

Gunathilagaraj, K., R.P. Soundararajan, N. Chitra and M. Swamiappan (1999). Odonata in the rice fields of Coimbatore. Zoos' Print Journal 14(6): 43-44.

Palot, M.J. and V.P. Soniya (2000). Odonata from Courtallam, Tamil Nadu, southern India. Zoos' Print Journal 15(7): 3001-3003.

Prasad, M. and R.K. Varshney (1995). A checklist of the Odonata of India including data on larval studies. Oriental Insects 29: 385-428. Tyagi, B.K. (1997). Dragonfly wealth of India - extant species. A preliminary systematic list. Zoos' Print 12(10): 3-10. 